\title{
MADINAH DAN PLURALISME SOSIAL (Studi atas Kepemimpinan Rasulullah Saw)
}

\author{
Yusno Abdullah Otta
}

\begin{abstract}
Abstraksi
Tulisan ini mencoba memetakan kembali bentuk masyarakat Madinah yang begitu pluralis di bawah kepemimpinan Muhammad Saw. Pluralitas yang ada pada masa itu tidak hanya dari satu sisi saja, yakni status sosial, namun yang lebih penting lagi perbedaan dari segi akidah, yang merupakan pokok dari semua bentuk perbedaan. Pluralitas dari segi akidah ini, dipandang oleh Rasulullah Saw. sebagai bagian yang mesti diatur dan diarahkan dengan sendi-sendi agama yang baik, agar bisa menjadi satu kekuatan yang sangat potensial. Sosok Muhammad yang akan kita bahas pada tulisan ini adalah Muhammad sebagai manusia biasa, terlepas dari segala atribut mukjizat yang dimiliki dan di-sandang olehnya sebagai utusan Allah untuk menyampaikan risalah dalam merenovasi serta mereformasi masyarakat Arab pra-Islam.
\end{abstract}

\section{Pendahuluan}

Pluralisme dalam hierarki tatanan sosial masyarakat adalah suatu keniscayaan yang tidak bisa dielakkan. Kondisi ini merupakan bentuk "keadilan" Tuhan atas manusia dan telah diciptakan demikian adanya, walau Tuhan "kuasa" menjadikan manusia itu umat yang satu (ummatan wahidah). Tetapi hal ini adalah kemustahilan, di samping menghilangkan khazanah keanekaragaman model dan bentuk manusia itu sendiri, juga menipiskan rasa kompetitif di antara mereka yang pada hilirnya adalah tidak adanya dinamisasi kehidupan, yang itu merupakan bumbu-bumbu kehidupan.

Konsep pluralisme ternyata bukan hanya menjadi filosofi ketatanegaraan masyarakat dunia dewasa ini serta bukan merupakan masalah 
baru yang dibicarakan oleh para sarjana modern. Konsepsi ini telah terformulasi bentuknya sejak awal pembentukan negara Madînah pasca Nabi Muhammad hijrah dari Mekkah ke kota itu. Masyarakat Madînah adalah masyarakat yang pluralis dan universal dalam berba- gai strata kehidupan sosial.

Muhammad Saw merupakan Nabi sekaligus Rasul yang diutus dan sebagai penutup para Nabi. Saperti para nabi sebelumnya, tugas utama Nabi Muhammad adalah menata masyarakatnya dan membimbing mereka ke arah kehidupan yang lebih harmonis dengan berasaskan sendi-sendi moral dan akhlak. Reformasi akhlak ini merupakan inti dasar dari misi Nabi Muhammad kepada manusia, sehingga kitab suci yang merupakan pedoman Nabi dan kaum Muslimin lebih ba- nyak berbicara dengan bahasa moral daripada bahasa hukum. Pada intinya, misi utamanya bukan memperkenalkan atau membawa ben- tuk agama baru bagi masyarakat Arab pada masa itu. Misi sucinya ini dideklarasikan sendiri oleh manusia pilihan Tuhan ini dalam salah satu hadisnya yang terkenal.

Madînah adalah kota yang memiliki beberapa keistimewaan dibanding daerah lain di semenanjung jazirah Arab, sehingga kota ini dipilih oleh Allah SWT sebagai tujuan hijrah Muhammad dari kota

Walaupun pada masa itu tentu bukan dikenal dengan istilah pluralisme seperti sekarang ini, namun tiap-tiap negara memiliki berbagai idiom politik berbeda tentangnya. Masyarakat India menyebutnya dengan Composite Society, Multing Pot Society orang Amerika Serikat mengistilahkannya, dan Multi Culturalism Society dipergunakan di Kanada serta negara kita mengunakan istilah Bhineka Tunggal Ika. Lihat Thoha Hamim, "Islam dan Civil Society, Masyarakat Madani: Tinjauan tentang Prinsip Human Rights, Pluralism, dan Religion Tolerance", dalam Jurnal Fakultas Tarbiyah IAIN Walisongo Semarang, bulan November, 1999.

Yang dimaksud dengan Muhammad adalah Nabi Muhammad Saw., penulisan tanpa Nabi dan Sallallahu 'Alaihi Wassallam adalah untuk membedakan pribadi beliau sebagai manusia biasa di satu sisi, dan di sisi lain sebagai Nabi yang diutus Allah. Walaupun, pada kenyataannya, kedua predikat tersebut sulit untuk dapat dipisahkan secara total dari diri Muhammad, karena kita membicarakan satu orang dengan predikat ganda, sebagai Nabi dan manusia biasa.

Lihat, Fazlur Rahman, Islam and Modernity, Transformation of an Intellectual Tradition, terj. Ahsin Mohammad, Bandung: Mizan, 1982, h. 16-17.

Dalam salah satu hadits terkenalnya, Rasulullah Saw bersabda: "Sesungguhnya aku diutus untuk menyempurnakan akhlak yang mulia." 
kelahirannya, Mekkah. Letak geografis Madinah yang secara alamiah memiliki kelebihan merupakan daerah yang cocok untuk dijadikan sebagai army basement, dibanding daerah lainnya. Sebelah Barat dari kota Madinah terdapat daerah yang luas dengan bukit-bukit bebatuan yang bercirikan vulkanik. Daerah ini pada musim panas akan terasa panas yang sangat menyengat dengan bentuk vulkaniknya yang runcing. Kondisi demikian tidak memungkinkan daerah ini mudah untuk dilalui oleh pejalan kaki atau penunggang kuda dan onta. Lokasi ini dikenal dengan sebutan 'Harrah Wabârah'. Bagian timurnya, seba- gaimana daerah baratnya dikenal dengan nama 'Harârah Waqîm'. Sementara bagian selatannya adalah daerah pertanian yang sangat luas dengan potensi hasilnya yang melimpah. Di daerah ini terdapat banyak pohon kurma, yang bisa menjadi perangkap dan ranjau alami. Satu-satunya daerah yang bisa dijadikan akses untuk masuk atau ke- luar melalui jalan darat dari Madinah adalah bagian Utara.

Masyarakat Madinah yang di dalamnya Nabi Muhammad ber- gaul merupakan bentuk masyarakat heterogen dan pluralis dari segi status sosial maupun akidah. Hal ini membawa implikasi pada misi dakwahnya. Tugas menyampaikan risalah ini tentu bukanlah pekerjaan yang mudah. Karena yang dihadapi bukanlah masyarakat yang dengan gampang menerima ajaran dan tradisi baru untuk menggantikan tradisi mereka yang sudah mengakar serta turun-temurun. Bentuk komunitas yang arogan dan tidak gampang menerima segala perubahan dan kemajuan sehingga mereka di cap "jahiliyah".

\section{Madînah Pra-hijrah}

Hijaz merupakan bagian dari jazira Arab, terletak di antara dataran tinggi Najd dan daerah pantai Tihanah. Di semananjung jazirah ini terdapat tiga kota utama yang merupakan sentralnya, yaitu, Tâif, dan dua kota bersaudara, Mekkah dan Madînah. Penduduknya adalah bangsa Arab dan bangsa Yahudi. Bangsa Arab tinggal di Mekkah dan Madînah serta Tâif, sedangkan bangsa Yahudi menempati Madînah.

Lihat, H.M.al-Hamid al-Husaini, Riwayat Hidup Nabi Besar Muhammad

Saw., t.t.: Waqfiyah al-Husaini Press, t.th., h. 457-8.

Lihat, Alfred Guillaume, Islam, England: Penguin Books, 1995, h. 457-458; 
Kota madinah sendiri pada masa pra-hijrah bernama Yatsrib. Pasca hijrah kota ini diganti menjadi Madinah. Penggantian nama dari Yatsrib menjadi Madinah dilakukan oleh Muhammad sendiri. Nama lengkapnya kota ini adalah Madinah al-Munawwarah, kota yang bersinar, bercahaya. Sejak pra-hijrah masyarakat Madinah telah dikenal sebagai komunitas yang pluralistik. Mayoritas penduduk kota Yatsrib, Madinah, adalah bangsa Yahudi. Mereka berdiaspora dari berbagai daerah di seputaran Madinah. Mereka melarikan diri dari kampung halaman karena tekanan dari penguasa yang otoriter dan kejam. Di daerah baru mereka membuka daerah koloni, salah satunya di tanah Hijaz, tepatnya di kota Madînah. Kota Madinah merupakan kota terkenal kedua di jazirah Arab setelah kota Mekkah.

Penduduk Yahudi Madînah mayoritas berasal dari suku Qainuqa, Bani Nâdhir, dan Bani Quraidha yang tinggal di pinggiran kota ini. Meskipun mereka berasal dari satu bangsa, Yahudi, namun mereka tidak pernah hidup rukun. Di antara mereka sering terjadi perti- kaian, bahkan tidak jarang menjurus pada peperangan antarsuku. Permusuhan antara suku Aus dan Khazarj adalah contoh dari sekian banyak pertikaian yang paling terkenal dan memakan waktu lama dalam masyarakat Madinah. Meskipun kedua suku ini berasal dari bangsa Arab, namun, harus diingat bahwa keduanya diprovokasi oleh bangsa Yahudi untuk selalu bermusuhan.

Data yang akurat tentang kapan asal mula kedatangan bangsa Yahudi ke Madînah sangat terbatas. Satu sumber mengatakan, bahwa pemukiman mereka di utara Arabia berawal pada zaman Nabi Musa. Hirschberg memberikan kesimpulan bahwa bangsa Yahudi telah berdomisili di Arabia menjelang awal abad pertama Masehi. Sukusuku terkemuka golongan Arab adalah 'Aus dan Khazraj yang berimigrasi dari Arabi Selatan, di samping suku-suku lain yang telah

dan lihat pula, J. suyuthi Pulungan, Prinsip-prinsip Pemerintah dalam Piagam Madinah: Ditinjau dari Pandangan Al-Quran, Jakarta: RajaGrafindo, 1996, h. 26.

Hannah Rahman, "Pertentangan Antara Nabi dan Golongan Oposisi Madinah", dalam H.L. Beck \& N.J.G.Kaptein (redaktur), Pandangan Barat terhadap Islam Lama, Seri INIS, Jilid IV, Jakarta: INIS, 1980, h. 60.

Philip K. Hitti, the History of the Arabs, London: The McMillan Press, Ltd., 1970, h. 10. 
menetap lebih dahulu di kota itu. Ada juga penduduk Madînah yang beragama Yahudi bukan dari bangsa Yahudi tetapi orang Arab. Mereka ini adalah bangsa Arab, seperti suku 'Aus dan Khazraj. Pola hidup dan sikap suku-suku Yahudi secara umum berbeda dengan orang-orang Arab, sekalipun di antara mereka terjadi hubungan perkawinan.

Madînah merupakan kota yang strategis dari segi politis dan ekonomis. Secara politik, daerah ini tidak dapat ditembus oleh musuh kecuali melalui jalur darat yang biasa dipakai sebagai jalur perdagangan, sebelah utara. Dan segi ekonomis, karena Madinah adalah daerah agraris yang menghasilkan berbagai komoditi unggulan dan utama bagi masyarakat Hijâz. Selain itu, Madinah merupakan "jalur sutra" para saudagar dan pedagang dari Yaman dan Mekkah. ${ }^{10}$

Semua kekuatan ini didominasi oleh pendatang, yakni bangsa Yahudi, sehingga menjadikan kedudukan mereka dipandang yang paling kuat dan berkuasa di kalangan mayoritas penduduk asli Madinah, yakni bangsa Arab. ${ }^{11}$ Bahkan, dalam beberapa kesempatan, mereka pernah menjadi pemegang otoritas dalam dominasi di berbagai sektor, baik ekonomi dan politik yang menjadikan memegang kendali politik yang membawa konsekuensi kepada ketergantungan bangsa Arab kepada mereka. Bangsa Arab baru bisa melepaskan diri dari belenggu ketergantungan ini pada sekitar awal abad ke-6 Masehi. ${ }^{12}$

Walaupun demikian, kaum Yahudi masih mendominasi kehidupan ekonomi Madînah sampai awal kedatangan Islam. Mereka masih menguasai lahan pertanian terbesar dan tersubur di kota ini, seperti Taimâ, Fadâ, dan Wadî al-Qurâ. Daerah-daerah ini merupakan lumbung bagi komoditi pertanian di Madinah. Di samping itu mereka juga menguasai betul pengetahuan di bidang pertanian, irigasi dan industri. ${ }^{13}$ Dan, dari segi kuantitas tidak kalah jauh dari jumlah pen-

W. Montgomery Watt, Muhammad, Prophet and Statesman, London:

Oxford University Press, 1969, h. 85.

10 Philip K. Hitti, The History of the Arabs, h. 12. Lihat pula, Pulungan, Prinsip-prinsip Pemerintah dalam Piagam Madinah, h. 31.

11 Hannah Rahman, "Pertentangan Antara Nabi dan Golongan Oposisi Madinah", h. 65.

12 Muhammad Husain Haekal, Hayât Muhammad, terjemahan Ali Audah, (Jakarta: Litera Antarnursa, 1990), h. 26-27.

13 J. Suyuthi Pulungan, Prinsip-prinsip Pemerintah dalam Piagam Madinah, h. 
duduk asli kota Madinah.

Fenomena ini, tentu saja, menyulut timbulnya kecemburuan sosial dari penduduk Madînah berbangsa Arab, terutama suku 'Aus dan Khazraj, sebagai suku yang dominan di Madînah di antara suku-suku Arab yang ada. Di sini nampak, bahwa, walaupun mereka satu agama, tetapi keadaan ini tidak membantu untuk mencairkan situasi, karena, bangsa Yahudi sering mengeksploitasi bangsa Arab dengan cara memberikan kredit dengan bunga tinggi, menjual barang dan senjata, bahkan mereka meminjamkan bibit pertanian kepada orang-orang Arab dengan sistem riba. Keadaan ini lambat laun membawa dampak yang kurang baik bagi bangsa Arab sendiri, karena dililit utang yang berlipat ganda. ${ }^{14}$

Suku 'Aus menempati daerah al-'Awâli (dataran tinggi) berdekatan dengan bani Quraidhah dan Nâdhir. Sedangkan, Khazraj berdomisili di dataran rendah yang bertetangga degan suku bani Quinuqâ'. Dari letak geografinya, suku 'Aus lebih beruntung daripada Khazraj, ka- rena, tanahnya lebih subur dibanding daerahnya Khazraj. Keadaan ini dimanfaatkan oleh bangsa Yahudi untuk memecah belah keduanya dengan politik devide et impera. ${ }^{15}$

Hasil provokasi bangsa Yahudi ini adalah terjadinya perang besar yang sangat terkenal yang dinamakan Bu'ats. ${ }^{16}$ Dalam peperangan ini

32.

14 Hannah Rahman, "Pertentangan Antara Nabi dan Golongan Oposisi Madinah", h. 69.

15 Muhammad Bayuni, Târîkh al-'Arab al-Qadîm, dalam Akram Dhiyauddin 'Umari, Madinan Society at The Time of the Prophet: Its Characteristics and Organization. Terj. Mun'im A.Sirry, Jakarta: Gema Insani Press, 1999, h. 66.

16 Perang Bu'ats adalah peperangan terakhir antara suku 'Aus dan Khazraj yang terjadi 5 tahun sebelum hijrah. "Bu'ats" adalah nama sebuah tempat di pinggiran kota Madinah. Perang ini terjadi akibat politiknya Yahudi Madinah yang menyusup ke dalam kelompok ke dua suku tersebut. Pada mulanya ke- menangan berada di pihak Khazraj, namun keadaan ini berbalik. Dalam pembalasan yang dilakukan oleh suku 'Aus, mereka membumihanguskan tempat tinggal suku Khazraj, bahkan, mereka ingin menghabisi semua suku Khazraj, namun niat mereka ini dilarang oleh Abu Qais al-Aslan. Dia berkata: "Bertetangga dengan mereka (suku Khazraj) lebih baik daripada bertentangga dengan Yahudi. Lihat, M.H. Haikal, Hayat Muhammad, h. 163-4; J. Suyuthi Pulungan, "Pertentangan Antara Nabi dan Golongan Oposisi Madinah", h. 6. 
suku 'Aus memperoleh kemenangan, atas bantuan bala tentara dari bani Nâdhir dan Quraidhah. Namun, kemenangan ini menyisakan prob- lema di antara mereka. Di satu pihak, kemenangan ini membanggakan mereka, tetapi di sisi lain menimbulkan kekhawatiran, bahkan berupa ancaman bahaya. Karena, secara praktis kekuatan bangsa Arab di kota Madînah tinggal suku 'Aus sendiri, walaupun mereka beraliansi dengan Nâdhir dan Quraidhah, tetapi kedua suku terakhir ini, hanyalah suku kecil, bila di banding dengan Khazraj. Secara politik mereka sudah tidak memiliki kekuatan lagi untuk membentengi bangsa Arab di kota kelahiran mereka dari ancaman dan rongrongan bangsa Yahudi. Titik lemah ini, yang dimiliki oleh bangsa Arab di Madînah, yang dimanfaatkan oleh para pendatang dalam memperkuat posisi mereka di daerah baru tersebut.

Menyadari hal ini, suku 'Aus berusaha mengadakan rekonsiliasi untuk menyatukan persepsi atas gap yang ada dengan suku Khazraj. Dari rekonsiliasi ini, disepakati untuk mengangkat seorang pemimpin yang mampu menjadi penengah atas semua perbedaan dan pertikaian yang ada. Mereka mengangkat Abdullah bin 'Ubay bin Salul dari suku Khazraj yang mereka pandang netral. Kenyataan ini merupakan bukti bahwa sebenarnya mereka mampu untuk mengurangi, bahkan menghilangkan, supremasi bangsa Yahudi atas mereka.

Perseteruan mereka, memicu timbulnya permusuhan, tapi ini ti- dak berarti bahwa mereka tidak mempunyai keinginan untuk hidup rukun dan damai. Keinginan kuat untuk hidup damai dan rukun ini yang mendorong mereka untuk mengundang Muhammad ke Madînah untuk menjadi pemimpin mereka dan mengajarkan apa yang dibawa oleh utusan Tuhan, yang telah mereka dengar sebagai ajaran baru. misi diundangnya Muhammad juga agar mampu men- jadi perekat atas perbedaan yang terjadi di antara mereka selama ini. Sehingga, ada beberapa orang di antara mereka yang datang ke Mekkah untuk bertemu sekaligus mengikrarkan sumpah setia di ha- dapan Muhammad.

Dari segi keyakinan dan agama, penduduk Madînah berbangsa Arab, tidak jauh berbeda dengan Mekkah, yakni penyembah berhala. Kondisi telah berjalan lama sebelum kedatangan bangsa Yahudi. 
Datangnya bangsa Yahudi mulai mengusik keadaan beragama ini. Me- reka selalu memprovokasi dan memproganda bangsa Arab Madinah dengan mengatakan bahwa keyakinan mereka akan dihancurkan oleh seorang Nabi yang akan datang. Bukan cuma itu, mereka juga menam- bahkan bahwa mereka akan dibunuh oleh nabi tersebut bila mereka tidak meninggalkan agama nenek moyang mereka itu. Dan, nabi ter- sebut datang ke dunia untuk memberi dukungan kepada bangsa Ya- hudi. ${ }^{17}$

Selain paganisme, ada di antara penduduk Arab yang menganut agama Masehi, baik yang teguh, seperti pendeta Bahîrah, atau hanya sekadar ikut-ikutan. Kelompok ini tersebar di beberapa tempat, seperti di Yaman, Suriah, Hirah, dan Abysinia. Situasi ini sudah ter- jadi sejak kerajaan Romawi masuk ke Hijaz pada abad ke-4. Di Ma- dînah sendiri, sedikitnya ada dua suku yang telah memeluk agama Kristen, yaitu suku Judâm dan 'Udhrâ. ${ }^{18}$

Aspek sosial politik masyarakat Madinah sangat beragam dan pluralistik, ini karena tidak adanya satu penguasa yang dapat menyatukan mereka dalam satu pimpinan. Keadaan ini berbeda dengan di Mekkah, pemegang kekuasaan politik dan ekonomi berada di tangan aritokrasi Quraisy, yang merupakan suku yang paling dominan di banding suku lain. Konflik yang berkepanjangan antara suku 'Aus dan Khazraj di Madînah, menjadikan mereka tidak pernah bersatu, walaupun mereka satu keyakinan dan kepercayaan. Kemenangan suku 'Aus atas Khazraj dalam perang Bu'ats, menunjukkan betapa lemahnya masyarakat Madînah dalam menggalang persatuan karena krisis kepemimpinan.

\section{Madinah Pasca-Hijrah}

Para sejarawan berbeda pendapat tentang rumusan golongan masyarakat yang terdapat dalam struktur Madînah pasca-hijrah. Hasan Ibrahîm Hasan, menggolongkannya menjadi empat bagian, yaitu golongan Anshâr, orang-orang Islam penduduk asli Madînah, Muhâjirîn, orang-orang Islam yang hijrah ke Madînah, kaum munafik dan

17 M. Haikal, Hayat Muhammad, h. 164.

18 J. Suyuthi Pulungan, "Pertentangan Antara Nabi dan Golongan Oposisi

Madinah", h. 37. 
musyrik; dan bangsa Yahudi yang sudah lama berada di Madînah. ${ }^{19}$

Struktur penduduk Madînah pasca-hijrah tentu saja lebih pluralistik ketimbang pra-hijrah. Mereka terdiri atas bangsa Arab Madinah yang telah masuk Islam di sebut kaum Anshâr, orang-orang Mekkah yang hijrah di sebut kaum Muhâjirîn, kelompok penduduk Madinah yang masih menganut paham paganis, golongan Yahudi yang terdiri dari berbagai suku, baik orang Arab maupun bangsa Yahudi sendiri, kaum munafik dan musyrik Madînah, dan kaum minoritas penganut agama Kristen. $^{20}$ Gambaran pluralistik masyarakat Madînah terdiri dari, suku, etnis, agama, asal daerah, ekonomi, agama dan keyakinan serta adat istiadat dan budaya. Keadaan ini menuntut mereka untuk bertindak sendiri dalam mewujudkan kepentingan tiap kelompoknya dalam mencapai kemajuan menurut prinsip dan filsafat hidup yang diyakininya serta budaya yang mengitarinya.

Di tinjau dari segi kebangsaan, penduduk Madînah terdiri dari dua bangsa yang berbeda, yaitu bangsa Arab dan bangsa Yahudi. Dari segi agama dan keyakinan, mereka ada yang masih memegang teguh keyakinan nenek moyang mereka, paganisme, ada kolompok Islam, Anshâr dan Muhâjirîn, Yahudi dan kelompok minoritas Kristen di pinggiran kota. Dari segi ekonomi, bangsa Yahudi yang memegang hampir semua sektor perekonomian, terutama pertanian dan indus- tri, dan mereka pula yang menguasai pasar. Mereka adalah kaum pen- datang yang menjadi tuan tanah dan menguasai modal, sementara bangsa Arab hanya menjadi the second class economic, pelayan di negeri sendiri. Dari segi struktur sosial dan kultur, mereka memiliki prejudice kesukuan (tribal prejudice), tapi berbeda dalam adat istiadat.

Bermacam instrumen dan elemen-eleman yang disebutkan di atas, dalam berbagai hal rentan dengan konflik, dan bisa menjadi pemicunya. Karena, komunitas masyarakat yang terdiri dari bermacam golongan memiliki perbedaan kepentingan dalam berbegai bidang; sosial, ekonomi, politik, dan agama yang cenderung saling mengeliminasi dan mencari celah untuk saling menyalahkan satu dengan lainnya,

19 Hasan Ibrahîm Hasan, Târîkh al-Islâm, Jilid I, Kairo: Maktabat al-Nahdhah al-Mishriyyah, 1979, h. 69.

20 J.S. Pulungan, "Pertentangan Antara Nabi dan Golongan Oposisi Madinah", h. 57. 
daripada mencari persamaan di antara mereka. ${ }^{21}$ Berbagai kelompok agama dan keyakinan yang berdomisili di Madînah dan sekitarnya juga disinggung dalam Alquran. ${ }^{22}$

Salah satu faktor yang menjadikan masyarakat Madînah lebih dapat menerima Islam di banding Masyarakat Mekkah, adalah karena watak masyarakatnya tidak arogan dan ekstrem. Asalusul keturunan mereka dari negeri Yaman yang memiliki watak yang halus dan lem-ut. Hal ini pernah digambarkan oleh Nabi Saw dalam salah satu sabdanya: "Telah datang kepada kalian penduduk Yaman yang berperangai halus dan berhati lembut". Dan, yang dimaksud oleh Ra- sulullah Saw dengan penduduk Yaman adalah suku 'Aus dan Khazraj yang tinggal di Madinah.

Kalaupun di antara kedua suku ini pernah terjadi peperangan karena provokasi dan propaganda Yahudi, seperti disebutkan di atas, tapi hal itu hanya sedikit banyak berpengaruh pada keinginan mereka untuk hidup damai dan aman dalam satu tempat. Keinginan itu nampak ketika mereka ('Aus dan Khazraj) bertemu dengan Muhammad pada musim haji. Pada waktu itu, mereka mendeklarasikan diri untuk ber- pisah dari penduduk bangsa Yahudi Madînah, bahkan mereka ber- baiat kepada Muhammad, sekaligus mengundangnya ke Madînah. ${ }^{23}$ Keadaan ini berlanjut tahun berikutnya ${ }^{24}$ di mana sepuluh orang da- tang menemui Muhammad di 'Aqabah dan menyatakan mengikuti ajaran yang dibawanya. ${ }^{25}$

21 Soerjono Soekamto, Sosiologi, Suatu Pengantar, Jakarta: Rajawali Press, 1982, h. 94.

22 QS. Al-Maidah (5) : 82; al-Taubah (9): 100, 101, 117. Ayat-ayat tersebut merupa- kan bukti bahwa Alquran juga dapat dijadikan sumber referensi sejarah, karena informasi yang diberikan terbukti dalam realitas historis.

23 Michael Cook, Muhammad, New York, Oxford Univesity Press, 1983, h. 19.

24 Sekembalinya dari Mekkah, mereka menceritakan peristiwa tersebut kepada penduduk Madinah, sehingga nama Muhammad begitu dikenal oleh penduduk Madinah. Pada bai'at pertama ini, mereka berjumlah enam orang. Mereka adalah Sa'ad b. Zararah dan 'Auf b. al-Harits, keduanya dari bani al-Najjar, Saraiq b. 'Amir b. Zuraiq dan Râfi' b. Malik b. 'Amr, keduanya dari bani Zuraiq; Sa' ad b. 'Ali b. Jasyiq dari bani Salmah; dan Quthbah b. 'Amr b. Hudaidah dari bani Sawad. Lihat Ibn. Ishâq, Sîrat Rasul Allâh. Terj. Inggris oleh Alfred Guillaume, The Life of Muhammad, Karachi: Oxford University Press, 1970, h. 38.

25 Adapula yang menamakan pertemuan kedua ini dengan sebutan Bai'at al-Nisâ'. 
Fenomena ini mengindikasikan bahwa ajaran Muhammad lebih diterima penduduk Madînah daripada penduduk Mekkah. Penduduk Mekkah sulit menerima Islam, kendatipun masyarakatnya bercorak homogen. Ini dikarenakan kekhawatiran mereka terhadap bias ajaran baru tersebut, yang bisa menghapus ajaran politheisme yang mereka anut secara turun-temurun dan telah berlangsung lama. Ditambah pula ajaran baru itu bisa menjadi ancaman terhadap struktur dan sta- tus sosial kelompok tertentu serta kelangsungan perdagangan mereka. Karena masalah mendasar adalah, di samping Islam membawa ajaran monoteisme, juga sangat menekankan keadilan sosial yang berkembang kepada penghapusan praktek riba/rente yang selama ini menjadi kebiasaan mereka, juga implementasi membayar zakat. ${ }^{26}$

\section{Sikap Islam Atas Pluralisme ${ }^{27}$}

Respons (agama) Islam atas supremasi kultural dan politis Barat modern dengan melahirkan tiga gerakan yang mana ketiganya memiliki kelebihan yang khas, yaitu modernisme Islam, tradisionalisme dan revivalisme ${ }^{28}$ atau sering orang menyebutnya dengan funda-

Nama ini diberikan oleh 'Ubâdah bin al-Shâmit, karena dalam pembai'atan tersebut turut dua orang wanita Madinah. Lihat, al-Hamid al-Husaini, Riwayat Hidup Nabi Besar Muhammad Saw., h. 457-458.

26 Fazlur Rahman, Islam, terj. Drs. S. Saleh, Jakarta: Bina Aksar, 1987, h. 21.

27 Pembahasan ini lebih menitikberatkan pada sikap Muhammad Saw. Yang diun- dang oleh penduduk Madinah yang akan diangkat menjadi pemimpin mereka di tengah-tengah masyarakat yang heterogen.

28 Modernisme Islam muncul pada awal abad ke-20 sebagai sikap yang berusa-ha untuk mereformulasi ajaran Islam sehingga bisa mengakomodasi ben-tuk perkembangan yang sehinga sejalan dengan semua norma modernisme. Penekanan dari gerakan ini adalah terciptanya keselarasan antara norma-norma modernisme dengan masalah-masalah Islam yang memiliki perbedaan dengan pandangan pemikiran modern, seperti hukum Syari'ah dan hak-hak perempuan. Sementara tradisionalisme adalah gerakan yang senantiasa meng-gaungkan konsep "kembali" kepada sumber asli ajaran Islam, yakni Alquran dan Hadits Nabi. Dalam pandangan sebagai pemikir Islam, seperti Hossein Nasr, bahwa Islam tradisional memiliki amunisi yang banyak dalam melahir-kan budaya alternatif sehingga kaum Muslimin mampu menghadapi supremasi intelektual Barat. Adapun revivalisme merupakan gerakan religio-politik yang memiliki perbedaan cara pandang dengan tradisionalisme atas warisan kul-tural Islam tradisionalis. Lebih lanjut lihat, Adnan Aslan, Religious Pluralism in 
mentalisme. ${ }^{29}$ Islam sebagai agama universal memandang bahwa se- mua manusia adalah sama dan sederajat dalam pandangan Pencipta. Manusia diciptakan dalam berbagi suku dan bangsa dengan tujuan untuk mengenal satu sama lain. ${ }^{30}$ Tidak ada yang lebih mulia di ha- dapan Allah kecuali siapa yang paling baik takwanya kepada-Nya. Nabi Saw. telah menegaskan hal ini dalam sabdanya: "Manusia itu keturunan Adam dan Adam itu dari tanah, tidak ada bedanya antara orang Arab dan bukan Arab".

Suatu masyarakat yang memiliki tatanan yang pluralis dan heterogen sebenarnya tersimpan kekuatan, yang dioptimalkan akan memberikan dampak positif bagi komunitas tersebut. Sejak pra-hijrah, struktur masyarakat Madînah telah pluralis dan heterogen. Terlebih setelah kedatangan kaum Muslimin yang berhijrah dari Mekkah. Struktur masyarakat seperti ini tidak ditemukan pada komunitas Mekkah. Keadaan ini, tentu saja, menguntungkan dari segi sosial ekonomi dan politik, karena pluralisme dapat memacu semangat kompetisi ke arah kebaikan bila diakomodasi dengan baik. Namun bisa menjadi bumerang bila tidak dikelola dengan baik. Dan Nabi Muhammad, sebagai pemimpin Bangsa Madinah, mampu menyatukan berbagai komponen masyarakat tersebut dalam suatu wadah yang disebut jamaah. Tan- tangan yang ada dijadikan peluang oleh Muhammad, dan sekaligus sebagai pembuktian akan kebenaran ajaran yang dibawanya, serta dia bukanlah seorang yang seperti mereka tuduhkan selama ini. ${ }^{31}$

Selama berada di Mekkah, Nabi Muhammad hanyalah seorang yang tidak memiliki masa depan yang menjanjikan dalam mendakwahkan ajarannya. Setiap dakwahnya selalu mentah dan termentahkan oleh arogansi masyarakatnya sendiri. Bentuk masyarakat yang dihadapinya adalah kelompok aristokrt, para eksploitir serta para konglomerat yang menguasai hampir seluruh sumber ekonomi kota. Mereka juga adalah para pembesar dan para tokoh masyarakat yang memiliki pengaruh

Christian and Islamic Philosophy: The Thought of John Hick and Seyyed Hossein Nasr, terj. Munir, Bandung: Alifya, 2004, h. 290-91.

29 Adnan Aslan, Religious Pluralism in Christian and Islamic Philosophy, h. 290.

30 Q S. Al-Hujurat (49): 13.

31 G.E. Van Grunebaum, Classical Islam, A History 600 - 1258, trans., Katherin Watson, Chicago: Aldine Publishing Company, 1970, h. 32. 
yang luas di jazirah Arab. Tentu saja bila disandingkan dengan seorang Muhammad, He is nothing. Dia hanyalah penggembala domba ber- sama pamannya. Yang dimilikinya hanya Risalah yang dibawa dan diyakininya bersumber dari Maha Pencipta, yaitu Islam. ${ }^{32}$

Hijrah ke Madînah merupakan awal dimulainya era baru perjuangan bagi Muhammad dalam berdakwah. Momen ini juga sekaligus membawa perubahan mendasar dalam sejarah pergerakan Islam. Nabi Muhammad dan kelompok pengikutnya dari Mekkah menemukan kemerdekaan beragama yang selama tidak didapatkan di tanah kelahirannya. Di kota baru ini, dia bertemu dengan orang-orang yang menerimanya, bahkan mereka berjanji akan melindunginya dari gangguan semua musuhnya. Kebebasan dan kemerdekaan dalam menjalankan ajaran agama yang didapatkan di kota ini, menjadi main point Muhammad Saw untuk hijrah ke sini. Misi hijrah tersebut tidak semata-mata bertujuan untuk memperluas wilayah dakwah an sich. Apatah lagi dibarengi keinginan untuk mengeruk keuntungan dan kekayaan, serta obsesi untuk menjadi orang terkenal di kalangan bangsa Arab, terutama sukunya, Quraish.

Langkah awal yang dilakukan Muhammad Saw di Madinah ialah memenuhi kebutuhan orang-orang yang bersertanya dalam berhijrah, Muhâjirîn. Mereka adalah para saudagar dan pedagang yang meninggalkan dagangan dan hartanya di Mekkah demi untuk berhijrah bersamannya. Untuk menangani ini, Muhammad Saw me- minta bantuan dan kebaikan kaum Anshâr, penduduk Madinah, untuk membantu saudara-saudara mereka dari Mekkah yang kehi- langan pekerjaan. Seruan muhammad ini dijawab oleh penduduk Madinah secara spontanitas. Ada di antara kaum Anshar yang mena- warkan kepada penduduk Mekkah tanah garapan untuk dijadikan perkebunan. ${ }^{33}$

Muhammad menanamkan rasa cinta kasih dalam lintas komunitas masyarakat Madinah terutama Muhâjirîn dan Anshâr. Membangun dan menyatukan kedua kelompok ini atas dasar cinta. Mendobrak

32 G.E. Van Grunebaum, Classical Islam, A History 600 - 1258, h. 32.

33 Ahmad Ibrâhîm Syarîf, Daulat al-Rasül fỉ al-Madînah, Kuwait: Dar al-Bayan, 1392/1972, h. 86. 
kekokohan egois yang telah lama bersarang dalam hati pribadi masing-masing kelompok dan menanamkan suatu kepercayaan bahwa orang-orang Mukmin yang benar adalah mereka yang hidup dalam masyarakat yang terbebas dari belenggu egoisme dan saling mengeksploitasi sesama mereka. Mukmin yang baik adalah orang yang merdeka secara pikiran maupun keyakinan. Dia selalu lapang dada dan menolong satu dengan lainnya dalam menghadapi setiap permasalahan hidup. ${ }^{34}$ Komunitas yang dibangun Muhammad Saw adalah kehidupan yang dilandasai saling menghormati: orang kaya tidak meremehkan orang miskin, pemimpin dan orang kuat dilarang mengeksploitasi orang lemah dan miskin.

Membangun sarana dan prasarana yang dapat dijadikan tempat untuk memperat silaturahmi antara Muhâjirîn dan Anshâr, dan tempat untuk mempelajari Islam. Muhammad mendirikan mesjid sebagai sentral kegiatan dakwah dan sosial. Mesjid adalah pusat kendali semua kegiatan masyarakat Madinah. Di mesjid pula, Muhammad mengakomodasi segala perbedaan yang terjadi antara Muhâjirîn dan Anshâr, bangsa Arab dan Yahudi dan antar orang Yahudi sendiri, yang mayoritas jumlahnya dibanding Muhajirin dan Anshar. Situasi ini, tentu saja membutuhkan undang-undang dan peraturan yang meng- atur dan mengikat setiap kelompok yang ada. Bila, pertama kali ke Madînah, Muhammad Saw tidak lebih hanya sebagai pemimpin agama (Nabi), maka, setelah situasi dan kondisi Madînah bisa dikendalikan. Nabi Muhammad mulai mengeluarkan dan menetapkan undang-undang yang berlaku bagi semua penduduk Madînah tanpa kecuali. Buah dari semua usaha ini mulai nampak ketika kaum Muslimin memenangkan perang Badar. Ketika itu, bangsa Yahudi di Madinah mulai merasa risau dengan keadaan ini. Kemenangan kaum Muslimin dalam Perang Badar ini menjadi titik awal Nabi Muhammad dalam memegang kendali atas kota Madinah. ${ }^{35}$

Perjuangan politik Nabi Muhammad diawali dengan langkah yang sangat strategis dengan mengadakan MoU (Memorandum of Understanding) dengan bangsa Yahudi yang dikenal kemudian dengan

34 Akram Dhiyauddin Umari, Madinan Society at The Time of the Prophet, $\mathrm{h}$. 78-79.

35 W.Mongomery Watt, Muhammad, h. 96.

492 
nama Piagam Madinah. ${ }^{36}$ Dalam Piagam ini, Nabi Muhammad mengadakan perjanjian perdamaian dan persahabatan dengan bangsa Yahudi. Dengan dokumen ini, menurut Watt, memberikan gambaran bahwa masyarakat Madinah sekarang dihormati/dihargai sebagai kons- titusi suatu unit politik dengan tipe baru dan di sebut "ummah". ${ }^{37}$ Ini- lah salah satu perjanjian politik yang memperlihatkan kemampuan Muhammad dalam mengakomodasi dan mengatur segala bentuk plu- ralisme yang berkembang dan mengitari masyarakat Madînah, yang terdiri etnis, suku, agama, sosial, ekonomi, dan politik.

Dengan perjanjian ini, di samping perjanjian lainnya, berarti kehi- dupan damai dan aman terwujud dalam kehidupan kota Madînah. Di tambah lagi, dengan langkah Muhammad mengganti nama kota dari "Yathrib"38 menjadi "Madînah" dengan julukan "al-Munawwarah". Langkah ini dianggap paling berani dan radikal, tapi juga dianggap sebagai kesuksesan besar dari strategi Muhammad dalam menyatukan heterogenisme dan pluralisme serta universalisme penduduk Madî- nah.

Perjanjian ini pula, menjadikan Muhammad Saw, yang dulunya dikenal sebagai pemimpin agama (Nabi dan Rasul), sekarang menjadi kepala negara sekaligus kepala pemerintah, yang memiliki kekuasaan mengeluarkan dan menetapkan hukum dan peraturan. Artinya ke- kuasaan arbitrase sekarang berada di tangan Muhammad Saw, dan beliau menjadi hakim atas segala pertikaian antar kelompok yang di Madînah. ${ }^{39}$

Dengan perjanjian tersebut, kaum Yahudi dan para hypocrate mem- peroleh perlindungan hukum dan keamanan, mereka memiliki ke- merdekaan dalam menjalankan segala aktifitas mereka tanpa merasa diganggu oleh kelompok lain yang ada di Madînah. ${ }^{40}$

36 Terlepas dari permasalahan apakah Piagam Madinah tersebut berjalan lama atau hanya beberapa saja. Hugh Kennedy menyebut dengan "Constitution of Madinah". Lihat, Hugh Kennedy, The Prophet and the Age of Chaliphates: the Islamic Near East From the Sixth to Seventh Century, London and New York: Longman Group, 1986, h 34; W. Montgomery Watt, Muhammad, h. 93.

37 Watt, Muhammad, h. 94.

38 Bernard Lewis, The Arabs in History, New York: Harper and Row, 1966, h. 32.

39 Watt, Muhammad, h. 96.

40 Muhammad al-Ghazali, Fiqh al-Sîrah, dalam Zainal Abidin ahmad, Piagam 


\section{Penutup}

Memandang dan mencermati sosok Muhammad Saw, kita akan dibuat tercengang dan terkagum-kagum, karena dia adalah "di atas manusia di bawah Tuhan", meminjam isitilah Alfonso De Lamartine. $^{41}$ Sehingga tidak mengherankan begitu banyak literatur yang menggambarkan mengenai pribadi mulia ini, tapi sepertinya semua itu belum cukup untuk mendeskripsikannya, karena keagungan dan kehebatannya di lihat dari kacamata natural human being.

"Sesungguhnya saya melukiskan Muhammad dengan lukisan yang sesuai dengan realita mungkin, yang saya baca dari berbagai buku, dan dari jiwa yang hidup dari pengikutnya... satu-satunya kekayaan yang ia miliki ialah: kejujuran, amanah, kebersihan, dan keikhlasan. Semuanya itu demi Allah dan merupakan kekayaan yang paling mulia dan agung. Demikianlah Muhammad di tengah-tengah masyarakat yang tidak mengenal akhlak dan tidak mengenal keluhuran." 42

Langkah yang diambil Muhammad Saw pasca-hijrahnya ke Madi- nah sungguh strategis, dan ini merupakan politik dasar dari terben- tuknya negara Madinah, dengan Muhammad Saw selaku kepala negara sekaligus kepala pemerintahan. Pemerintahan Nabi Muhammad diba- ngun atas dasar keikhlasan dalam rangka menyebarkan risalah Allah SWT. Pembentukan negara ini, bukan berorientasi pada kekuasaan dan eksploitasi manusia, tapi, justru sebaliknya, untuk mendobrak dan mengikis habis akar warisan dan kebiasaan yang sudah berjalan lama di kalangan masyarakat pada masa itu berupa supremasi manusia atas manusia. Dan inilah yang menjadikan Muhammad Saw begitu dikenang dan dihormati baik oleh kawan maupun lawan-lawannya. Serta ini pula yang menjadikannya sebagai tokoh berpengaruh dalam urutan pertama, di banding tokoh dunia lainnya, seperti Napoleon

Nabi Muhammad Saw., Konstitusi Negara Tertulis yang Pertama di Dunia, (Ja- karta: Bulan Bintang: 1973), h. 52-3.

41 Salah seorang orientalis kelahiran Bordeaux, Perancis tahun 1790 dan meninggal tahun 1869. Ia termasuk penyair ternama dan penganut aliran romantisme, di antara buku prosanya telah diterjemahkan ke dalam bahasa Arab dengan Al-Safar ila al-'Asyraq.

42 Monsieur Amiel Parnamcam (1857-1924) dalam Al-syaikh Khalil Yasin, Muhammad 'Inda 'Ulama al-Gharb, terj. Salim Basyarahil, Jakarta: Gema Insani Press, 1995, h. 118. 
Bonaparte atau Julius Cesar, dan di banding Nabi dan raja lainnya, seperti Isa, Daud dan Musa serta Sulaiman. ${ }^{43}$

Ada seorang bijak pernah berkata: 'Supaya orang mengetahui secara mendalam apa sebenarnya isi seruan yang dikumandangkan seseorang, pertama-tama ia harus mengenal pribadi pembawanya". Allah sendiri memuji manusia yang agung dengan, yang ikut merasakan pen- deritaan kaumnya, yang selalu menginginkan kebaikan umatnya, dan amat tinggi kasih sayangnya sesama orang Mukmin. ${ }^{44}$

Wa Allah A'lam bi Muradihi

43 Lihat, Michael Hart, Seratus Tokoh yang Paling Berpengaruh dalam Sejarah, (Jakarta: Pustaka Jaya, 1982).

44 Q.S. al-Taubah (9) : 128. 


\section{Daftar Pustaka}

Ahmad, Zainal Abidin Piagam Nabi Muhammad Saw., Konstitusi Negara Tertulis yang Pertama di Dunia, (Jakarta: Bulan Bintang, 1973).

Cook, Michael, Muhammad, (New York: Oxford Univesity Press, 1983). Guillaume, Alfred, Islam, (England: Penguin Books, 1995).

Grunebaum, G.E. Van, Classical Islam, A History 600 - 1258, translate, Katherin Watson, (Chicago: Aldine Publishing Company, 1970), h. 32.

Hamim, Thoha, "Islam dan Civil Society (Masyarakat Madani): Tinjauan tentang Prinsip Human Rights, Pluralism, dan Religion Tolerance", dalam Jurnal Fakultas Tarbiyah IAIN Walisongo Semarang, bulan No- vember, 1999.

Hitti, Philip K., History of The Arabs, (London: The McMillan Press, Ltd., 1970).

Haekal, Muhammad Husain, Hayât Muhammad, terjemahan Ali Audah, (Jakarta: Litera Antarnusa, 1990).

Ibrahîm Hasan, Hasan, Târîkh al-Islam, jilid I, (Kairo: Maktabat alNahdhah al-Mishriyyah, 1979).

Ishâq, Ibn., Sîrat Rasul Allâh . Terj. Inggris oleh Alfred Guillaume, The Life of Muhammad, (Karachi: Oxford University Press, 1970).

Kennedy, Hugh, The Prophet and the Age of Chaliphates: The Islamic Near East From the Sixth to the Seventh Century, (London and New York: Longman Group, 1986).

Lewis, Bernard, The Arabs in History, (New York: Harper and Row, 1966).

Pulungan, J. suyuthi,Prinsip-prinsip Pemerintah dalam Piagam Madinah: Ditinjau dari Pandangan Al-Quran, (Jakarta: RajaGrafindo, 1996).

Rahman, Fazlur, Islam, terj. Drs. S. Saleh, (Jakarta: Bina Aksar, 1987).

------------, Islam And Modernity, Transformation of an Intellectual Tradition, terj. Ahsin Mohammad, (Bandung: Mizan, 1982).

Rahman, Hannah, 'Pertentangan Antara Nabi dan Golongan Oposisi Madinah, dalam H.L. Beck \& N.J.G.Kaptein (redaktur), Pandangan Barat terhadap Islam Lama, Seri INIS, Jilid IV, (Jakarta: INIS, 1980). 
Soekamto, Soerjono, Sosiologi, Suatu Pengantar, (Jakarta: Rajawali Press, 1982).

Syarîf, Ahmad Ibrâhîm, Daulat al-Rasül fi al-Madînah, (Kuwait: Dar alBayan, 1392/1972).

Watt, W. Montgomery, Muhammad, Prophet And Statesman, (London: Ox- ford University Press, 1969). 